UDC: $339.138: 502.3$

\title{
MARKETING INSTRUMENTS TO PROMOTE GREEN INVESTMENT: DECLINING GREENWASHING
}

DOI 10.30838/ P.ES.2224.261218.204.339

\author{
Pimonenko T., PhD in Economics \\ Lyulyov O. PhD in Economics \\ Liulova L.

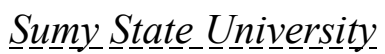

The paper deals with the analysis of preconditions to promote green investment. The authors allocated the main features and principals of green investment. The results of the analysis of EU experience showed that green investment is one of the ways to attract additional finance recourses for supporting the country's green growth. In this case, the authors allocated the main barriers which limit the green investment spreading in Ukraine: lack of the legislation bases; non-existing the universal approach to define and classify green investment and assets; the existing stereotype that green investment is a non-profitable investment; greenwashing concept which used by companies and etc. Besides, one of the ways to overcome the issues and boost green investment market is using the effective marketing instruments with the purpose to promote green investment among main stakeholders. In the paper, the authors allocated the main marketing instruments to whispered green investment. The results of the analysis showed that one of the factors which restrict the efficiency of promoting green investment is greenwashing. Thus, greenwashing defined as a gap between two behaviours: the lowest level of green performance and short-term positive talking about green thinking. In this case, with the purpose to develop Ukrainian green brand greenwashing should be declined through the controlling from the government authorities. In the paper, the authors proposed to implement a regulation which controls the publishing of nonfinancial reports in open access on the obligatory bases. The authors highlighted, that well-developed green investment market and effective marketing communications of promoting them have a positive impact on the country's brand through the forming country's green brand. As a positive consequence, it could provoke the improving of Ukrainian investment climate which attracts the additional foreign green investment.

Keywords: greenwashing; green investment; stakeholder; marketing; brand УДК: 339.138:502.3

\section{МАРКЕТИНГОВІ ІНСТРУМЕНТИ ПРОСУВАННЯ ЗЕЛЕНИХ ІНВЕСТИЦІЙ: МІНІМІЗАЦІЯ «ГРІНВОШІНГ»}

DOI 10.30838/ P.ES.2224.261218.204.339

Пімоненко Т., к.е.н., Люльов О. к.е.н., Люльова Л.

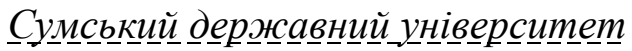
У статті авторами проаналізовано та систематизовано основні передумови розвитку та просування зелених інвестицій у вітчизняній практиці. Авторами

(C) Pimonenko T., PhD in Economics, Lyulyov O. PhD in Economics, Liulova L., 2018 
виокремлено основні параметри та особливості зелених інвестицій. Результати аналізу досвіду країн ЄС показали, що зелені інвестиції є одним із ефективних методів залучення додаткових фінансових ресурсів для підтримки зеленого зростання країни. У даному контексті авторами було виокремлено основні бар'єри, які стримують поширення зелених інвестицій в Україні, а саме: відсутність ефективного законодавчого регулювання; відсутність універсального підходу до трактування дефініції зелені інвестиції, їх класифікації, а також принципів ідентифікації зелених активів; наявний стереотип, про неприбутковість зелених інвестицій. У статті зазначено, що одним з шляхів подолання визначених бар'єрів та стимулювання розвитку інвестиційного ринку країни є використання ефективних маркетингових інструментів 3 метою поширення зелених інвестицій серед основних стейкхолдерів. У статті систематизовано основні маркетингові інструменти для промоції зелених інвестицій. Результати аналізу показали, що одним 3 факторів, які обмежують ефективність промоції зелених інвестицій грінвошінг. У рамках дослідження грінвошінг визначається як розрив між двома поведінками: найнижчим рівнем зеленої ефективності та декларацією зеленого іміджу. У цьому випадку, з метою розвитку зеленого бренду країни, використання грінвошінг повинно бути мінімізовано через контроль державних органів. У статті авторами запропоновано закріпити на державному рівні публічне розкриття не фінансової звітності. Визначено, що ефективне функціонування ринку зелених інвестицій та ефективний набір маркетингових комунікацій промоції зелених інвестицій опосередковано матиме позитивний вплив на зелений бренд країни. У результаті це сприятиме відновленню інвестиційного клімату в країні, що у свою чергу призведе до припливу додаткових іноземних зелених інвестицій.

Ключові слова: грінвошінг; зелені інвестиції; стейкхолдер; маркетинг; бренд

Introduction. The ongoing economic issues, financial imbalance, political and social conflicts provoke the declining of Ukrainian investment climate which leads to the capital outflow. Therefore, the level of trust among the foreign investor is at the lowest level which also has a negative impact on countries image and brand. From year to year the volume of foreign direct investment has being decreased. In this case, it is necessary to develop and implement an effective mechanism to recover the country's investment climate, image and brand. From the other side, the mainstream among worldwide investors is taking to account the main principals of sustainable development. It means, that investors consider not only economic aims so also green aspects during the investment decisions. Therefore, the results of the analysis of EU experience showed that developing of green investment market could be one of the ways to attract new capital into the Ukrainian economy. At the same time, the developing of the mechanism of green investment market should be taking with the developing of marketing instrument to promote green investing among the main stakeholders of the green investment market. 
Literature review. The huge range of investigations focused on allocating the main principals and features of green investments $[2,4,10-13$, 15]. Thus, Chygryn O. and Krasnyak V. [2] allocated the practice aspects to develop the Ukrainian environmental investment market. Delmas M. highlighted the main features of green growth and allocate the issues with developing of green investment market [4]. The results of the previous investigations Pimonenko T. in the papers [10-13] showed that the main barriers are misunderstanding and non-existing the universal approach to define green investment. Thus, the authors Pimonenko T. and Lushyk K. in the paper [11] defined green investment as an investment in green assets. In this case, it is necessary to develop the universal approach of classifying green investment.

The scientists Pimonenko T., Leus D., Us J. and Fedyna S. in the paper [13] proved that the second barrier is a stereotype among investors, that green investment is not profitable. With this purpose, it is necessary to develop effective marketing communications among the stakeholders. It should be noted, that most current investigation analyses green investment market developing only through the formatting of the fundamental principles eliminating the promotion mechanism. It should be noted, that a lot of papers $[4,5,9,14,16,18]$ of the scientists Delmas M., Burbano C. V., Toffel M. W., Peattie K., Siano A., Testa F., Vos L. focused on the developing concept of the green marketing which tries to pay attention to green parameters of the product. However, the exists papers on green marketing didn't take to account the features of green investment.

In this case, the results of analysis proved the necessity of further investigation of the unsolved issues as follows: to allocate the main parameters of green investment as a product from the marketing point of view; to develop the marketing instruments to promote green investment considering the Ukrainian conditions; to identify the main problems which limit the promotion of green investment and as a consequence decrease the level of trust to Ukraine from the main stakeholders.

The aim of the paper is identifying the main functions and features of green investment as a marketing product with the purpose to indicate the main marketing communications to promote them.

Results. Thus, in 2017 the foreign direct investment has decreased by $30 \%$ compared to the 2014 year (figure 1). Mostly, it was the results of the military and the political conflicts which provoked the transformation process from focusing on Russian to EU market. 
At the same time, in 2017 compare with 2016 the total volume of foreign investment increased which was the results of improving relationship with EU countries. Thus, it was necessary to provide proactive mechanism to recover the Ukrainian investment market. As a way it could be the promotion of countries green brand which attract the green investment to the Ukrainian economy.

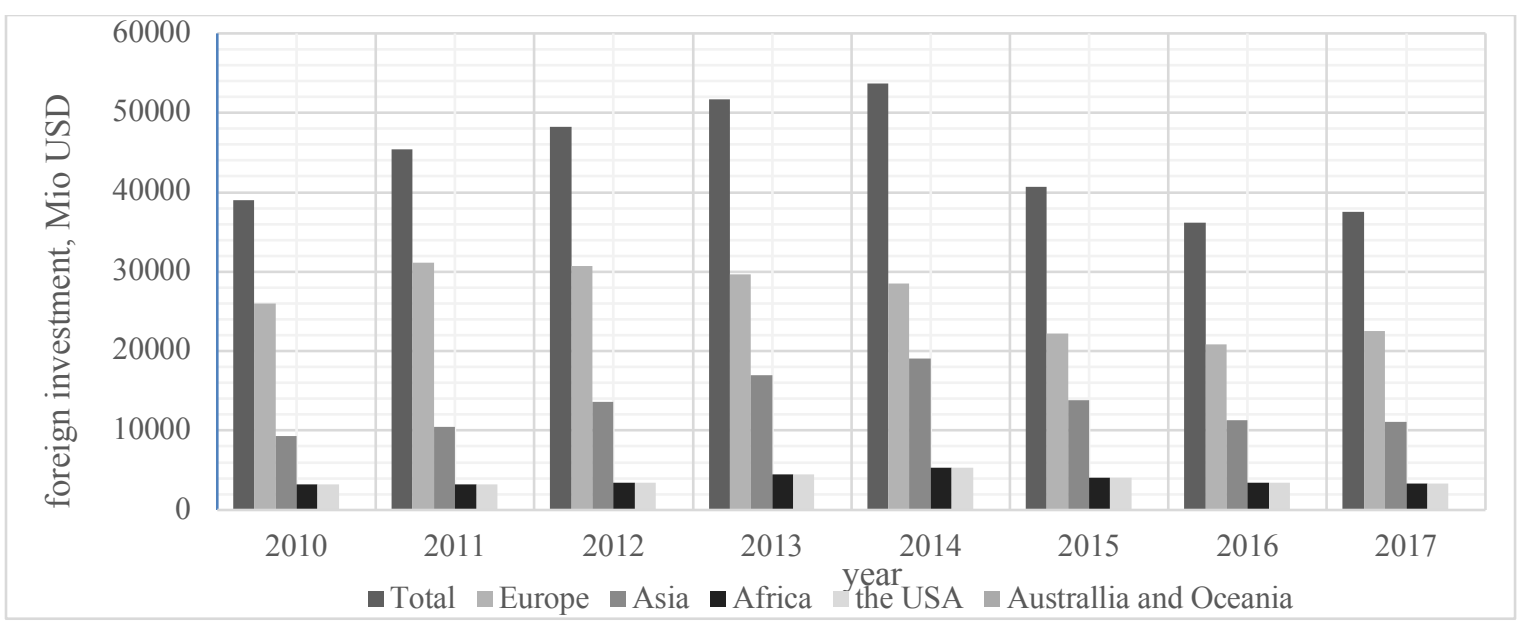

Fig. 1. The dynamic of foreign investment in Ukraine 2010-2017, Mio USD

Sources: developed by the authors on the basis of [1]

At the same time, in 2017 compare with 2016 the total volume of foreign investment increased which was the results of improving relationship with EU countries. Thus, it was necessary to provide proactive mechanism to recover the Ukrainian investment market. As a way it could be the promotion of countries green brand which attract the green investment to the Ukrainian economy.

The results of the analysis showed that main barriers which restrict the developing of green investment market are:

- non-existing of the fundamental theory of green investment with allocation the universal approach to defining green investment, main stakeholders, their role and duties;

- exists of the stereotype that green investment isn't profitable;

- lack of a legislative base of green investment market;

- non-existing the universal system of accounting green assets and investment;

- insufficient supporting policy to support green investors;

- the lowest level of trust to the Ukrainian investment market and greenwashing; 
- non-existing effective marketing policy to promote green brand and image in Ukraine and etc.

The results of the analysis in the previous researching [10-13] allowed allocating the main features of green investment as follows:

- investing in green assets (green projects, green growth, sustainable development and etc.);

- supporting long-term goals;

- investment's goals correspond to the principals of sustainable development (SD);

- public character: participating in the wide circle of stakeholders justified that investment decisions should be accepted using the principals of complexity;

- considering different investment's sources, combined in time and space, their forms and types;

- differ from of investment that provides the state, interstate, own, mixed forms of organization of social and economic activities of natural users;

- considering specific properties of self-regulation and heal itself ecosystems its individual components $[2,11]$.

Thus, one of the problems is stereotype among investors which could be overcome through the effective marketing instruments. In this case, the traditional marketing concept should be transformed considering the main features of green investment.

Traditionally the main elements of marketing are product; price; positioning and promoting. Taking to account the features of green investment and general market concept, the following elements of green investment marketing could be allocated:

- product - green investment;

- green price;

- place considering features of green investment;

- green promotion;

- people (stakeholders);

- green passion (branding);

- greenwashing.

The conceptual model of green investment was presented in Figure 2. According to the proposed model (Figure 2) green investment is the main product which is the focus of the marketing. As the main feature of green investment is balancing between the ecological, social and economic benefits 
it was necessary to develop a promotion program which focused on all these three benefits. In this case, the benefits of sustainable development goals should be included in the promotion program of green investment. The main goal should be formatting positive thinking about green investment.

The traditional placement should be done considering the green aspect of investment. The efficiency of marketing program depends on the correct placement which could lead to success or to break the green brand of investment. Therefore, the marketing program should use modern instruments (online advertising) combining with government support.

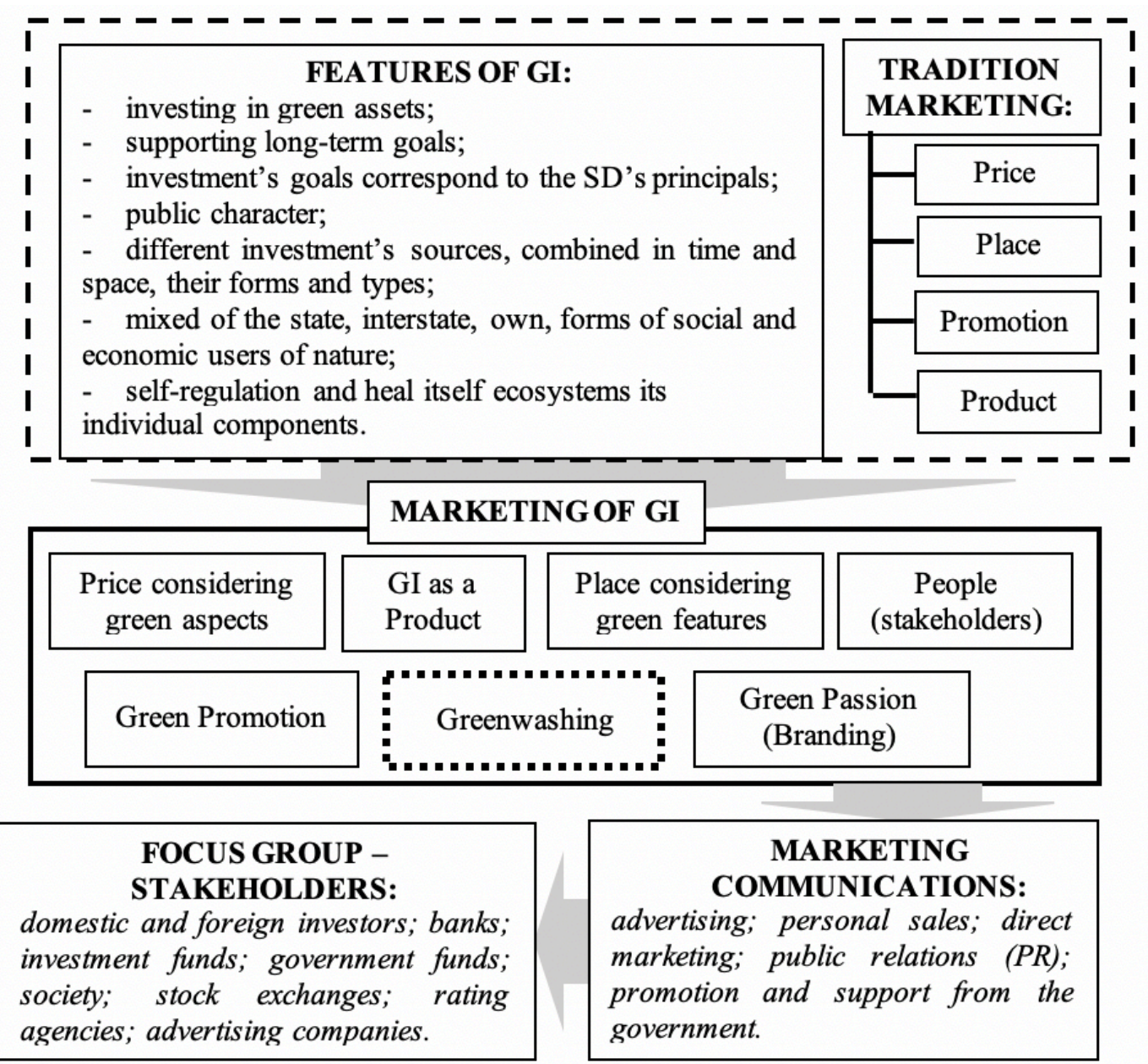

GI-green investment

Fig. 2. The principal framework of the marketing of green investment Sources: developed by the authors

Should be noted, that green passion and branding become the most significant factor which influences on green investment promoting. Communication with the main stakeholders is a key element to know how to improve the promotion of green investment based on their thoughts and feedbacks. 
Greenwashing is the current form of PR technologies. Firstly, this term was described by the scientist Jay Westervelt in 1986 in an essay on explaining how hotels tried to promote green idea through the using of the towels more than one time. In that way hotel whish to reduce costs on washing through the declaring the concerning of green issue. Jay Westervelt described the behaviour which focuses on profitability, not on environmental issues.

The results of analysis $[4,5,16]$ showed that greenwashing could be defined as the gap between two behaviours: the lowest level of green performance and short-term positive talking about green thinking.

According to the paper [14], the scientists defined greenwashing as a big gap between declaration and real practice. Thus, the real practice means initiatives which correspond to the main principals of sustainable development. Therefore, greenwashing develops only green talking and green myth about the brand which could be destroyed at any time.

It should be noted, that mostly greenwashing using with the purpose to demonstrate ecological benefits and achievements instead of real investment in green projects which decline negative impact on the environment. Mostly, greenwashing used by the industry companies (oil, chemical, automobile and etc.) to develop green images and to promote their products as eco-friendly. Thus, according to the experts' calculation (on the first Day of Earth) in 1970 the companies had been spent on greenwashing more than $\$ 1$ billion, it was much more than they spent on green technologies [14].

The results of the analysis showed, that using of greenwashing lead to formatting negative attitude to 'green' as a brand. The latest scandal with Volkswagen company on CO2 emission leads not only to the paying of $\$ 24.7$ billion and as a consequence to decline the trust level to the company which had the negative impact on company's brand which led to the loss of sales - up to $\$ 34.5$ billion $[17,18]$.

Thus, with the purpose to attract additional green investment, the greenwashing should be declined and controlled by the government authorities. One of the perspective ways on solving abovementioned issues was implementing the transparency principals in the company activities. According to that, the non-financial reports should be published on the regular bases, in open access and as obligatory.

Conclusion. The findings proved that transformation from the traditional to the green growth model requires additional financial recourses. In this case, the perspective way is developing and promoting green investment among the 
main stakeholders. At the same time, it is necessary to develop the effective range of marketing communications to promote green investment which leads to the formatting of green country's brand and increase the level of trust from the foreign investor to Ukraine. Therefore, greenwashing should be declined through the implementation of transparency principal on the publishing of the non-financial reports

Funding: This research was funded by the grant from the Ministry of Education and Science of Ukraine (№ g/r 0117U003932)

\section{СПИСОК ВИКОРИСТАНИХ ДЖЕРЕЛ:}

1. Державна служба статистики України. [Електронний ресурс]. - Режим доступу: http://www.ukrstat.gov.ua

2. Чигрин О. Ю. Теоретико-прикладні аспекти розвитку екологічного інвестування в Україні / О. Ю. Чигрин, В. С. Красняк // Маркетинг і менеджмент інновацій. - 2015. №3. C. 226-234.

3. Banerjee S. Environmental Marketing (Green Marketing Rudiments) / S. Banerjee // IOSR Journal of Business and Management (IOSR-JBM), 7th International Business Research Conference IESMCRC Special Issue. - 2011. - Vol. 2. P. 69-74. [Електронний ресурс]. Режим доступу: http://www.iosrjournals.org/iosr-jbm/papers/7th-ibrc-volume-2/24.pdf

4. Delmas M. Organizational responses to environmental demands: Opening the black box / M., Delmas, M. W. Toffel. // Strategic Management Journal. - 2005. - Issue 29. P. 1027-1055.

5. Delmas M. The drivers of greenwashing / M. Delmas, B. V. Cuerel // California Management Review. - 2011. - Issue 54. P. 64-87

6. Dkhili H. (2018). Environmental performance and institutions quality: evidence from developed and developing countries / H. Dkhili // Marketing and Management of Innovations. - 2018. - Issue 3. P. 333-244.

7. Hens L., Karintseva, O., Kharchenko, M., \& Matsenko, O. The States Structural Policy Innovations Influenced by the Ecological Transformations / L. Hens, O. Karintseva, M. Kharchenko, O. Matsenko // Marketing and Management of Innovations. - 2018 . - Issue 3. P. 290-301. http://doi.org/10.21272/mmi.2018.3-26

8. Lyulyov O. National Brand as a Marketing Determinant of Macroeconomic Stability / O. Lyulyov, O. Chygryn, T. Pimonenko // Marketing and Management of Innovations, 3, 142-152.

9. Peattie, K. (1995). Environmental Marketing Management-Meeting the Green Challenge / K. Peattie // Pitman Publishing, UK. - 1995.

10. Pimonenko T. Ukrainian Perspectives for Developing Green Investment Market: EU Experience / T. Pimonenko // Economics and Region. - 2018. - № 4(71). - P. 35-45.

11. Пімоненко Т. В. Зелене інвестування: досвід ЄС для України / Т. В. Пімоненко, К. В. Лущик // Вісник Сумського державного університету. Серія Економіка. - 2017. - № 4. - C. 121-127. 
12. Пімоненко Т. В. Екологічні фондові індекси: зарубіжний досвід та уроки для України / Т.В. Пімоненко, Ю.О. Мирошниченко, О.М. Коробець, О.І. Литвиненко // Вісник Сумського державного університету. Серія Економіка. - 2017. - №3 . - С. 61-67.

13. Ус Я. О. Сучасні еколого-економічні інструменти забезпечення сталого розвитку / Т. В. Пімоненко, Я. О. Ус, Д. В. Леус, С. М. Федина // Вісник Сумського державного університету. Серія Економіка. - 2017. - №2. - С. 57-67.

14. Siano A. More than words: Expanding the taxonomy of greenwashing after the Volkswagen scandal / Siano, A., Vollero, A., Conte, F. ,Amabile, S. // Journal of Business Research. 2015. - Issue 71. P 27-37. doi:10.1016/j.jbusres.2016.11.002

15. Sotnyk I. Management of Renewable Energy Innovative Development in Ukrainian Households: Problems of Financial Support / I. Sotnyk, I. Shvets, L. Momotiuk, Y. Chortok // Marketing and Management of Innovations. - 2018. - Issue 4. P. 150-160. http://doi.org/10.21272/mmi.2018.4-14

16. Testa F. Internalization of Environmental Practices and Institutional Complexity: Can Stakeholders Pressures Encourage Greenwashing? / F. Testa, O. Boiral, F. Iraldo // Journal of Business Ethics. - 2015. - Issue 147(2). P. 287-307.doi:10.1007/s10551-015-2960-2

17. The Domino Effect of Volkswagen's Emissions Scandal. (2015). [Електронний ресурс].Режим доступу: https://www.forbes.com/sites/greatspeculations/2015/09/28/the-dominoeffect-of-volkswagens-emissions-scandal/\#3258544d282b

18. Vos L. What is Green Marketing? [Електронний ресурс]. - Режим доступу: https://learn.g2crowd.com/green-marketing

\section{REFERENCES:}

1. Derjavna Slujba Statistici [State Statistic Service]. (2018). Retrieved from: http://www.ukrstat.gov.ua

2. Chygryn, O., Krasnyak V. (2015). Theoretical and applied aspects of the development of environmental investment in Ukraine. Marketing and Management of Innovations. 3, P. 226-234.

3. Banerjee, S. (2013). "Environmental Marketing (Green Marketing Rudiments)”, IOSR Journal of Business and Management (IOSR-JBM), 7th International Business Research Conference IESMCRC Special Issue, vol. 2, pp. 69-74. Retrieved from: http://www.iosrjournals.org/iosr-jbm/papers/7th-ibrc-volume-2/24.pdf

4. Delmas, M., \& Cuerel, Burbano V. (2011). The drivers of greenwashing. California Management Review, 54, 64-87

5. Delmas, M., \& Toffel, M. W. (2008). Organizational responses to environmental demands: Opening the black box. Strategic Management Journal, 29, 1027-1055.

6. Dkhili, H. (2018). Environmental performance and institutions quality: evidence from developed and developing countries. Marketing and Management of Innovations, 3, 333244. http://doi.org/10.21272/mmi.2018.3-30 
7. Hens, L., Karintseva, O., Kharchenko, M., \& Matsenko, O. (2018). The States Structural Policy Innovations Influenced by the Ecological Transformations. Marketing and Management of Innovations, 3, 290-301. http://doi.org/10.21272/mmi.2018.3-26

8. Lyulyov, O., Chygryn, O., and Pimonenko, T. (2018). National Brand as a Marketing Determinant of Macroeconomic Stability. Marketing and Management of Innovations, 3, 142-152. http://doi.org/10.21272/mmi.2018.3-12

9. Peattie, K. (1995). Environmental Marketing Management-Meeting the Green Challenge, Pitman Publishing, UK

10. Pimonenko T. Ukrainian Perspectives for Developing Green Investment Market: Eu Experience. Economics and Region No 4 (71) - 2018.

11. Pimonenko T., Lushyk K. (2017). Zelene investuvannya: dosvid EU dlya Ukrayiny [Green investing: EU experience for Ukraine]. Visnyk Sums'koho derzhavnoho universytetu. seriya Ekonomika. - Bulletin of Sumy State University. Economy Ser., 3, 61-67. 10.21272/ 1817-9215.2017.2-08

12. Pimonenko T., Myroshnychenko Yu., Korobets O., Lytvynenko O. (2017). Ekolohichni fondovi Indeksy: zarubizhniy dosvid ta uroky dlya Ukrayiny [Ecological stock indexes: foreign experience and lessons for Ukraine]. Visnyk Sums'koho derzhavnoho universytetu. seriya Ekonomika. - Bulletin of Sumy State University. Economy Ser., 4, 121-127.

13. Us J., Pimonenko T., Leus D., Fedyna S. (2017). Suchasni ekoloho-ekonomichni instrumenty zabezpechennya staloho rozvytku [The modern ecological and economic instruments for sustainable development]. Visnyk Sums'koho derzhavnoho universytetu. seriya Ekonomika. - Bulletin of Sumy State University. Economy Ser., 2, 57-67.

14. Siano A. More than words: Expanding the taxonomy of greenwashing after the Volkswagen scandal / Siano, A., Vollero, A., Conte, F. ,Amabile, S. // Journal of Business Research. 2015. - Issue 71. P 27-37. doi:10.1016/j.jbusres.2016.11.002

15. Sotnyk, I., Shvets, I., Momotiuk, L., \& Chortok, Y. (2018). Management of Renewable Energy Innovative Development in Ukrainian Households: Problems of Financial Support. Marketing and Management of Innovations, 4, 150-160. http://doi.org/10.21272/mmi .2018.4-14

16. Testa, F., Boiral, O., \& Iraldo, F. (2015). Internalization of Environmental Practices and Institutional Complexity: Can Stakeholders Pressures Encourage Greenwashing? Journal of Business Ethics, 147(2), 287-307.doi:10.1007/s10551-015-2960-2

17. The Domino Effect of Volkswagen's Emissions Scandal. (2015). Retrieved from: https:/www.forbes.com/sites/greatspeculations/2015/09/28/the-domino-effect-ofvolkswagens-emissions-scandal/\#3258544d282b

18. Vos L. (2019). What is Green Marketing? Retrieved from: https://learn.g2crowd.com/green-marketing 